\title{
Response of Antioxidative Enzymes to Cadmium Stress in Leaves and Roots of Radish (Raphanus sativus L.)
}

\author{
Hossam Saad EL-BELTAGI ${ }^{1}$, Amal A. MOHAMED ${ }^{2)}$, Mohamed M. RASHED ${ }^{1)}$ \\ ${ }^{1)}$ Cairo University, Faculty of Agriculture, Department of Biochemistry, P.O. Box. 12613, Gamma st, Giza, Cairo, Egypt; lbltg@yahoo.com \\ ${ }^{2)}$ Department of Plant Biochemistry, National Research Center (NRC), El Behouth, Egypt
}

\begin{abstract}
Presented study has demonstrated that exposure of plants to toxic heavy metal Cd results a reduction in plant growth. Varied concentrations of $\mathrm{CdCl}_{2}$, ranging from 0.0 to $50 \mathrm{ppm}$ in the germinating media reduced leaf area of radish plant, chlorophyll and carotenoid contents. Greater loss of chlorophyll b content than chlorophyll a was observed especially under 50 ppm Cd exposure. With regards to the distribution of $\mathrm{Cd}$ in roots and leaves, the obtained data showed that the maximum accumulation of $\mathrm{Cd}$ occurred in roots followed by leaves. Generally, Fe, Zn, Mn and $\mathrm{Cu}$ declined in leaves compared to the roots. Furthermore, substantial increases were observed in antioxidant enzymes, such as catalase (CAT), glutathione S-transferase (GST) and peroxidase (POD), in Cd-stressed plants in comparison with control. The $\mathrm{Cd}$ stress also induced several changes in CAT and POD isozyme profiles and enhanced their activities. The results suggest that the reduction of leaf area and pigment content together with antioxidant enzymes and isozyme patterns can be used as indicators to Cd contamination.
\end{abstract}

Keywords: cadmium, radish, chlorophyll, catalase, peroxidase, glutathione S-transferase

Abbreviations: CAT: Catalase; POD: Peroxidase; SOD: Superoxide dismutase; GSH: Reduced glutathione; CDNB: 1-Chloro-2,4dinitrobenzene; GST: Glutathione S-transferase; ROS: Reactive oxygen species; $\mathrm{H}_{2} \mathrm{O}_{2}$ : Hydrogen peroxide; ${ }^{\circ} \mathrm{OH}$ : Hydroxyl radicals; O2 ' - Superoxide radical; PAGE: Polyacrylamide gel electrophoresis; PAA: Polyacrylamide

\section{Introduction}

Cadmium (Cd) is one of most toxic pollutants found in air, water and soil and is non-essential for plants. Cd interacts with photosynthetic, respiratory and nitrogen metabolism on plants resulting in poor growth and low biomass accumulation growth inhibition, reduction of root length, leaf area and even plant death, although the mechanisms involved in its toxicity are still not completely understood (Sanitá di Toppi and Gabbrielli, 1999; Snadalio et al., 2001). Cd produces oxidative stress possibly by generating free radicals and reactive oxygen species (ROS) as superoxide radicals $\left(\mathrm{O}_{2}{ }^{-}{ }^{-}\right)$, hydrogen peroxide $\left(\mathrm{H}_{2} \mathrm{O}_{2}\right)$ and hydroxyl radicals $\left(. \mathrm{OH}^{2}\right)$ (Hendry et al., 1992; Halliwell and Gutteridge, 1989). These toxic species react with lipids, proteins, pigments, and nucleic acids and cause lipid peroxidation, membrane damage, inactivation of enzymes, thus affecting cell viability for their protection. In order to deleterious effect of ROS, plant cells are equipped with several antioxidant enzymes and antioxidant compounds as sited by Dixit et al. (2001). Cd accumulates immediately in roots, later in the stem and finally in the leaves (Dixit et al., 2001). Photosynthesis is also sensitive to Cd, chlorophyll being one of the targets as well as enzymes involved in $\mathrm{CO}_{2}$ fixation (Somashekaraiah et al., 1992). Cadmium toxicity is also correlated with disturbances in the uptake and distribution of macro- and micro-nutrients in plants
(Gussarson et al., 1996). The accumulation of oxygen free radicals mediated oxidative damage is prevented in the cell by peroxidase (POD), particularly in the cell wall, or by catalase (CAT) in the peroxisome (Azevedo et al., 1998; Polidoros and Scandalios, 1999). Glutathione is also a precursor of phytochelations. The conjugation of glutathione to a variety of hydrophobic, electrophilic and cytotoxic substrates is accomplished by multifunctional enzymes glutathione S-transferases (GSTs). These enzymes play a regulatory role in heavy metal-induced oxidative stress (Dixit et al., 2001). Cd toxicity can also modulate the expression of isozymes in plant tissue. For example, Van Assche and Clijsters (1986) detected two isoperoxidases in both roots and leaves which were absent in the control phaseolus plant. The aim of the present study was to explore the possibility of using some biochemical and molecular methods for the prediction of $\mathrm{Cd}$ toxicity on radish plant.

\section{Materials and methods}

\section{Plant material and stress conditions}

The healthy, homogenous seeds of radish (Raphanus Sativus L.) were subjected to surface sterilization with $0.1 \%$ sodium hypochlorite solution for $10 \mathrm{~min}$ and then rinsed with double distilled water. After $24 \mathrm{~h}$ imbibitions of seeds in water, seedlings were raised in sand cultures in 
plastic pots saturated with either Hoagland nutrient solution (Hogland and Arnon, 1950), which served as control or nutrient solutions supplemented with $\mathrm{CdCl}_{2}$ to achieve concentrations of $1,2.5,5,10,25$ or $50 \mathrm{ppm} \mathrm{Cd}^{2+}$ which served as treatment solution. Pots were maintained at field saturation capacity and received control and respective treatment solutions when needed to saturate the sand and the plants were watered as needed. Pots were kept for growth of seedlings at $28 \pm 1^{\circ} \mathrm{C}$ under $80 \%$ relative humidity and $12 \mathrm{~h}$ photoperiod with $40-50 \mu \mathrm{mol}^{-2} \mathrm{~s}^{-1}$ irradiance. All treatments were tested in four replications. For further study, the plant samples were collected at 40 day from pot culture and the biochemical parameters were analyzed.

\section{Leaf area \\ Leaf area was estimated by leaf area-meter model LI- 3000 .}

\section{Determination of $C d$ content}

To determine the amount of absorbed cadmium in the seedling, fresh root/shoot samples were surface sterilized with $1 \mathrm{M} \mathrm{HCl}$ and then with $1 \mathrm{mM} \mathrm{Na} \mathrm{N}_{2}$ EDTA to resolve excess surface bound $\mathrm{Pb}$ and then dried in oven at $70^{\circ} \mathrm{C}$ for 3-4 days. Dried samples were ground to a fine powder in a mortar and pestle and digested using the $\mathrm{HNO}_{3} / \mathrm{HClO}_{4}$ digestion method. Digested samples were dissolved in deionized distilled water and lead content was estimated using atomic absorption spectrometer (Unicam Sp 1900 model). $\mathrm{Pb}$ content of roots and shot was calculated in $\mathrm{mg}$ $\mathrm{g} \mathrm{DW}^{-1}$, where DW stands for dry weight.

\section{Pigments contents}

Chlorophyll $a(\mathrm{Chl} a)$, chlorophyll $b$ (Chl $b$ ), and carotenoids were extracted and estimated according to the method of Lichtenthaler (1987). About $100 \mathrm{mg}$ of leaves from each $\mathrm{Pb}$ treatment was cut into tiny segments and kept in $10 \mathrm{ml}$ of chilled $80 \%$ acetone in a capped glass tube. After $48 \mathrm{~h}$ extraction in dark at $4^{\circ} \mathrm{C}$, the leaf segments were well-extracted for residual pigments. The contents of Chl $a$, Chl $b$ and carotenoids were measured at $666 \mathrm{~nm}, 653$ $\mathrm{nm}$ and $470 \mathrm{~nm}$, respectively. Pigment contents were calculated in $\mathrm{mg} \mathrm{g} \mathrm{FW}{ }^{-1}$.

\section{Preparation of crude enzyme extracts}

The method described by Vitória et al. (2001) was used to prepare the crude enzymes extracts. In this method, roots' and leaves' tissues were homogenized in a chilled pastel and mortar with $100 \mathrm{mM}$ potassium phosphate buffer ( $\mathrm{pH}$ 7.5) containing $1 \mathrm{mM}$ EDTA, $3 \mathrm{mM}$ DL-dithiothreitol and 5\%(w/v) insoluble polyvinyl pyrrolidone. The homogenates were centrifuged at $10.000 \mathrm{~g}$ for $30 \mathrm{~min}$ and then the supernatants were kept stored in separate aliquots at $-20^{\circ} \mathrm{C}$ until the analysis.

\section{Protein determination}

Soluble protein was estimated by using the Coomassie Brillent Blue G-250 reagent according to the method of Bradford (1976) with bovine serum albumin as standard.

\section{Antioxidant enzyme activities}

Peroxidase (POD) activity was assayed according to the method of Hemeda and Klein (1990). A $100 \mathrm{ml}$ of reaction mixture contained $10 \mathrm{ml}$ of $1 \%$ guaiacol (v/v), 10 $\mathrm{ml}$ of $0.3 \% \mathrm{H}_{2} \mathrm{O}_{2}$ and $80 \mathrm{ml}$ of $50 \mathrm{mM}$ phosphate buffer ( $\mathrm{pH}$ 6.6). Enzyme extract ( $75 \mu \mathrm{l})$ was added to the reaction mixture in a final volume of $3 \mathrm{ml}$. The increase in absorbance due to oxidation of guaiacol (extinction coefficient $26.6 \mathrm{mM}^{-1} \mathrm{~cm}^{-1}$ ) was monitored at $470 \mathrm{~nm}$. Enzyme activity was expressed as units $\mathrm{min}^{-1} \mathrm{mg}^{-1}$ protein.

For measurement of the catalase (CAT) activity the method of Aebi (1983) was used. The $3 \mathrm{ml}$ reaction mixture comprised of $50 \mathrm{mM}$ sodium phosphate buffer $(\mathrm{pH}$ 7.0), $20 \mathrm{mM} \mathrm{H}_{2} \mathrm{O}_{2}$ and a suitable aliquot of enzyme. Decrease in the absorbance was taken at $240 \mathrm{~nm}$ (molar extinction coefficient of $\mathrm{H}_{2} \mathrm{O}_{2}$ was $\left.0.04 \mathrm{mM}^{-1} \mathrm{~cm}^{-1}\right)$. Enzyme activity was expressed as units $\mathrm{min}^{-1} \mathrm{mg}^{-1}$ protein.

Glutathione S-transferase (GST) was determined using the method of Habig and Jacoby (1981). The reaction mixture consisted of $100 \mathrm{mM}$ potassium phosphate buffer (pH 6.5), 1 mM EDTA, 1 mM 1-chloro 2,4-dinitrobenzene (CDNB), $1 \mathrm{mM}$ reduced glutathione and enzyme extract. The enzyme activity was measured at wave length of $340 \mathrm{~nm}$. The activity of the enzyme was calculated using the extinction coefficient of the conjugate $9.6 \mathrm{mM}^{-1} \mathrm{~cm}^{-1}$ and expressed as units $\mathrm{min}^{-1} \mathrm{mg}^{-1}$ protein.

\section{Native gel electrophoresis and isoenzyme staining}

PAGE for peroxidase POD and catalase CAT isoenzymes assay was performed with $7 \%(\mathrm{w} / \mathrm{v})$ polyacrylamide gel as described by Laemmli (1970). POD isoenzymes were detected by the Ros Barcelo method (Ros Barcelo, 1987). The gels were rinsed in water and the gel was stained in a solution containing $0.06 \%(\mathrm{v} / \mathrm{v}) \mathrm{H}_{2} \mathrm{O}_{2}, 0.1 \%(\mathrm{w} / \mathrm{v})$ benzidine and $0.1 \%(\mathrm{v} / \mathrm{v})$ acetic acid at room temperature till it reached the brown colour. CAT isoenzymes were detected by the Woodbury method (Woodbury et al. 1971). Gels were incubated in $0.01 \% \mathrm{H}_{2} \mathrm{O}_{2}$ for $10 \mathrm{~min}$ and developed in a $2 \%(\mathrm{~m} / \mathrm{v}) \mathrm{FeCl}_{3}$ and $2 \% \mathrm{~K}_{3} \mathrm{Fe}(\mathrm{CN})_{6}(\mathrm{~m} / \mathrm{v})$ solution for $10 \mathrm{~min}$ until the colourless bands appeared.

\section{Statistical analysis}

Statistical analysis were done using SPSS (version 10) program. Mean and standard error were descriptive measures of quantitative data using the analysis of variance test (ANOVA) for independent samples. P $\leq 0.05$ were considered significant. Values reported here are means of three replicates. 
78

\section{Results and discussion}

\section{Leaf area}

Results pertaining to the effects of various concentrations of $\mathrm{Cd}$ on the average of leaf area of radish at harvest time under prevalent treatments are represented on Fig. 1. Data showed that the leaf areas of radish plants reflect the toxicity effects of cadmium. In low concentrations of $\mathrm{Cd}$ ( 1 and $2.5 \mathrm{ppm}$ ), slightly effects were noticed. In these treatments, the reduction of leaf areas reached 62.66 and $56.36 \mathrm{~cm}^{2}$, respectively. Moderately inhibitory effects were seen in other Cd treatments $(5,10$ and $25 \mathrm{ppm})$. At these concentrations, the values of leaf areas reached 51.13, 46.36 and $41.56 \mathrm{~cm}^{2}$ with $\mathrm{Cd}$ treatments, respectively. At high concentration of $\mathrm{Cd}(50 \mathrm{ppm})$ very strong inhibitory effects were observed and reached the maximum value $\left(31.87 \mathrm{~cm}^{2}\right)$. The reduction of leaf area could be attributed to toxic Cd levels, which induce negative effects on some key metabolic processes coupled to growth in radish (Van Assche et al., 1984). The impact of Cd uptake by living cells has been shown to be drastic, normally leading to cell death depending on metal dose and time-length of exposure (Vitória et al., 2001).

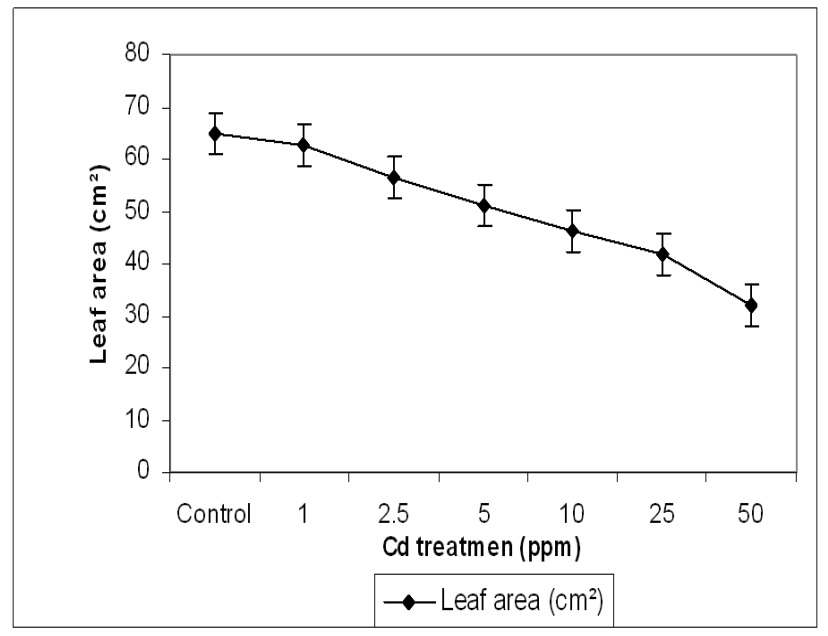

Fig. 1. Effect of various concentrations of $\mathrm{Cd}\left(\right.$ as $\left.\mathrm{CdCl}_{2}\right)$ on the average of leaf area $\left(\mathrm{cm}^{2}\right)$ of radish plants grown in sand culture at the harvest time ( 40 days)
Cd accumulation and micronutrient contents

Regarding to the data of cadmium accumulation in Tab. 1, gradually increases in $\mathrm{Cd}$ accumulation in roots and leaves could be noticed,while $\mathrm{Cd}$ content in growth media was increased. The $\mathrm{Cd}$ concentration was ranged between 1.3 and $112 \mathrm{ppm}$ in leaves and 5 to $206 \mathrm{ppm}$ in roots. It means a progressive accumulation of $\mathrm{Cd}$ in roots which was translocated to leaves. Values in Tab. 1 also indicated that the concentration of Fe, $\mathrm{Zn}, \mathrm{Mn}$ and $\mathrm{Cu}$ were decreased by increasing $\mathrm{Cd}$ concentration in the growth media. The lowest concentrations of micronutrients were found at $50 \mathrm{ppm} \mathrm{Cd}$ in both leaves and roots. Nevertheless this increase is not toxic to the plant and may be rendering to continuous addition of nutrient solution but its translocation from the roots to the leaves differ from one element to other. These results were in harmony with those obtained by several authors in many plants including radish (Vitória et al., 2001; Mohamed et al., 2009), peas (Dixit et al., 2001; Sandalio et al., 2001), maize and pea plants (Lozano-Rodriguez et al., 1997), groundnuts (Stefanov et al., 1995) and beans (Wouter et al., 2002). They found an accumulation of cadmium in plants with increasing cadmium concentration in the growth media.

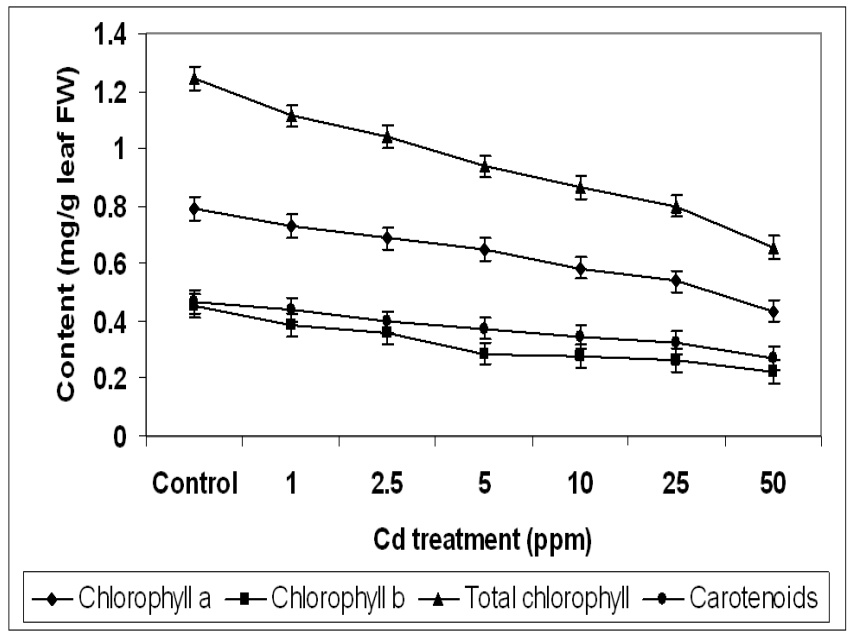

Fig. 2. Levels of chlorophyll and carotenoid contents $\left(\mathrm{mg} \mathrm{g}^{-1}\right.$ leaf FW) of Cd treated radish plants grown in sand culture at the harvest time (40 days). FW: fresh weight

Tab. 1. Cd accumulation and micronutrient contents in leaves and roots of radish plants at harvest time (40 days of growth)

\begin{tabular}{|c|c|c|c|c|c|c|c|c|c|c|}
\hline \multirow{2}{*}{$\begin{array}{c}\text { Treatment } \\
(\mathrm{ppm})\end{array}$} & \multicolumn{2}{|c|}{$\mathrm{Cd}$} & \multicolumn{2}{|c|}{$\mathrm{Fe}$} & \multicolumn{2}{|c|}{$\mathrm{Zn}$} & \multicolumn{2}{|c|}{$\mathrm{Mn}$} & \multicolumn{2}{|c|}{$\mathrm{Cu}$} \\
\hline & Leaves & Roots & Leaves & Roots & Leaves & Roots & Leaves & Roots & Leaves & Roots \\
\hline 0 & $1.3 \pm 0.1^{\mathrm{f}}$ & $5 \pm 0.5^{g}$ & $817 \pm 40^{a}$ & $948 \pm 23^{a}$ & $36.3 \pm 1.2^{a}$ & $18 \pm 1.5^{c}$ & $327 \pm 15^{a}$ & $302 \pm 7.1^{a}$ & $39 \pm 1.5^{a}$ & $77 \pm 4.6^{a}$ \\
\hline 1 & $12 \pm 0.5^{c}$ & $30 \pm 4.0^{f}$ & $755 \pm 39^{a}$ & $711 \pm 18^{b}$ & $33.3 \pm 0.6^{a}$ & $21 \pm 1.0^{\mathrm{abc}}$ & $270 \pm 36^{\mathrm{b}}$ & $281 \pm 4.0^{b}$ & $32 \pm 1.7^{\mathrm{b}}$ & $66 \pm 3.5^{b}$ \\
\hline 2.5 & $15 \pm 0.6^{\mathrm{c}}$ & $50 \pm 5.0^{c}$ & $657 \pm 40^{\mathrm{b}}$ & $700 \pm 8.0^{\mathrm{b}}$ & $32.6 \pm 2.1^{a}$ & $20 \pm 1.7^{\mathrm{bc}}$ & $183 \pm 14^{c}$ & $257 \pm 6.7^{c}$ & $28 \pm 1.0^{c}$ & $59 \pm 3.6^{c}$ \\
\hline 5 & $23 \pm 0.6^{\mathrm{d}}$ & $91 \pm 4.2^{\mathrm{d}}$ & $617 \pm 16^{b c}$ & $641 \pm 13^{c}$ & $22.0 \pm 2.7^{b}$ & $21 \pm 1.8^{\mathrm{abc}}$ & $145 \pm 8.1^{\mathrm{d}}$ & $220 \pm 11^{d}$ & $24 \pm 0.6^{\mathrm{d}}$ & $51 \pm 2.0^{d}$ \\
\hline 10 & $41 \pm 2.1^{\mathrm{c}}$ & $112 \pm 5.0^{c}$ & $555 \pm 30^{\mathrm{cd}}$ & $566 \pm 11^{\mathrm{d}}$ & $20.6 \pm 1.2^{b}$ & $24 \pm 1.1^{\mathrm{a}}$ & $136 \pm 5.1^{\mathrm{de}}$ & $143 \pm 7.5^{\mathrm{c}}$ & $19 \pm 1.1^{\mathrm{c}}$ & $40 \pm 1.5^{c}$ \\
\hline 25 & $60 \pm 4.5^{\mathrm{b}}$ & $148 \pm 9.0^{\mathrm{b}}$ & $517 \pm 42^{d}$ & $462 \pm 8.0^{c}$ & $16.6 \pm 3.5^{c}$ & $22 \pm 1.6^{\mathrm{ab}}$ & $109 \pm 8.1^{\mathrm{cf}}$ & $121 \pm 3.1^{\mathrm{f}}$ & $16 \pm 1.5^{f}$ & $35 \pm 1.2^{f}$ \\
\hline 50 & $112 \pm 1.5^{a}$ & $206 \pm 2.0^{a}$ & $400 \pm 66^{\mathrm{c}}$ & $310 \pm 7.0^{\mathrm{f}}$ & $13.2 \pm 3.0^{c}$ & $18 \pm 1.3^{c}$ & $98 \pm 7.8^{f}$ & $105 \pm 7.0^{\mathrm{g}}$ & $12 \pm 1.1^{\mathrm{g}}$ & $30 \pm 0.6^{\mathrm{g}}$ \\
\hline LSD & 3.490 & 8.601 & 72.831 & 24.047 & 3.855 & 2.795 & 29.12 & 12.13 & 2.228 & 4.87 \\
\hline
\end{tabular}

a,b,c, Means within column different litter differ significantly $(\mathrm{P}>0.5)$ from each other 
Tab. 2. Specific activities of antioxidant enzymes in leaves and roots of radish plants

\begin{tabular}{|c|c|c|c|c|c|c|}
\hline \multirow{2}{*}{$\begin{array}{l}\text { Treatment } \\
(\mathrm{ppm})\end{array}$} & \multicolumn{2}{|c|}{ CAT unit g protein ${ }^{-1}$} & \multicolumn{2}{|c|}{ GST unit mg protein $^{-1}$} & \multicolumn{2}{|c|}{ POD unit mg protein ${ }^{-1}$} \\
\hline & Leaves & Roots & Leaves & Roots & Leaves & Roots \\
\hline 0 & $5.72 \pm 0.76^{c}$ & $3.68 \pm 0.64^{\mathrm{c}}$ & $0.029 \pm 0.0008^{\mathrm{c}}$ & $0.025 \pm 0.0007^{\mathrm{c}}$ & $4.9 \pm 0.05^{\mathrm{g}}$ & $10.4 \pm 0.12^{s}$ \\
\hline 1 & $7.18 \pm 0.96^{c}$ & $9.97 \pm 1.42^{\mathrm{d}}$ & $0.035 \pm 0.0012^{\mathrm{dc}}$ & $0.042 \pm 0.0014^{\mathrm{d}}$ & $6.0 \pm 0.08^{f}$ & $36.5 \pm 0.24^{f}$ \\
\hline 2.5 & $19.4 \pm 0.58^{d}$ & $15.4 \pm 1.21^{\mathrm{c}}$ & $0.037 \pm 0.0008^{\mathrm{d}}$ & $0.047 \pm 0.0011^{\mathrm{d}}$ & $8.0 \pm 0.27^{\mathrm{c}}$ & $46.2 \pm 2.52^{c}$ \\
\hline 5 & $20.4 \pm 1.26^{\mathrm{d}}$ & $15.7 \pm 0.97^{c}$ & $0.055 \pm 0.0028^{c}$ & $0.048 \pm 0.0033^{\mathrm{d}}$ & $12.2 \pm 0.14^{\mathrm{d}}$ & $57.3 \pm 0.54^{\mathrm{d}}$ \\
\hline 10 & $33.1 \pm 0.84^{c}$ & $31.9 \pm 1.25^{\mathrm{b}}$ & $0.059 \pm 0.0030^{c}$ & $0.113 \pm 0.0044^{c}$ & $14.3 \pm 0.37^{c}$ & $126 \pm 2.7^{c}$ \\
\hline 25 & $58.8 \pm 1.24^{\mathrm{a}}$ & $49.8 \pm 1.00^{\mathrm{a}}$ & $0.103 \pm 0.0051^{\mathrm{b}}$ & $0.142 \pm 0.0054^{\mathrm{b}}$ & $24.9 \pm 0.79^{b}$ & $132 \pm 1.39^{\mathrm{b}}$ \\
\hline 50 & $46.6 \pm 2.74^{b}$ & $30.2 \pm 1.14^{b}$ & $0.133 \pm 0.0054^{a}$ & $0.189 \pm 0.0139^{\mathrm{a}}$ & $32.6 \pm 0.58^{a}$ & $145 \pm 3.61^{\mathrm{a}}$ \\
\hline LSD & 2.403 & 1.945 & 0.0057 & 0.0102 & 0.724 & 3.395 \\
\hline
\end{tabular}

a,b,c, Means within column different litter differ significantly $(P>0.5)$ from each other

\section{Chlorophyll and carotenoid contents}

Data of chlorophylls and carotenoids are shown in Fig. 2. The control leaves recorded the highest contents of chlorophylls and carotenoids while the lowest values were found in plants treated with the highest concentrations of Cd.

Chlorophyll $a$ content at highest $\mathrm{Cd}$ concentration (50 ppm) was reached $0.436 \mathrm{mg} \mathrm{g}^{-1}$ leaf fresh weight compared to control $\left(0.793 \mathrm{mg} \mathrm{g}^{-1}\right.$ leaf fresh weight). A significant reduction was noticed in chlorophyll $b$ content with different $\mathrm{Cd}$ treatments. The level of chlorophyll $b$ in $50 \mathrm{ppm}$ of Cd treatment reached to $0.223 \mathrm{mg} \mathrm{g}^{-1}$ leaf fresh weight compared to control $\left(0.454 \mathrm{mg} \mathrm{g}^{-1}\right.$ leaf fresh weight). The data showed that chlorophyll $b$ was more reduced at the Cd concentrations than chlorophyll a. Furthermore, gradual decrease of carotenoid content has been noticed according to $\mathrm{Cd}$ concentration increase. With $\mathrm{Cd}$ treatments $(1,2.5,5,10,25$ and $50 \mathrm{ppm})$ of carotenoid contents recorded $0.437,0.396,0.375,0.345,0.324$ and $0.271 \mathrm{mg} \mathrm{g}^{-1}$ leaf fresh weight, respectively. Generally, the reduction of chlorophyll and carotenoids content may be due to $\mathrm{Cd}$ induced inhibition of $\delta$-aminolaevulinic acid hydratase $(\delta$-ALA). This enzyme converts $\delta$-ALA into porphobilinogen in the synthesis of chlorophyll (Wouter et al., 2002). Also Cd inhibits the protochlorophyllide reductase by $\mathrm{SH}$-interaction between heavy metals and $\mathrm{SH}$ group on the enzyme (Van Assche and Clijsters, 1990). In addition, heavy metals can cause substitution of $\mathrm{Mg}$ atom in chlorophyll molecules and led to breakdown in photosynthesis process as stated by Kupper et al. (1998) and Helene et al. (1998). The increases of Cd concentrations in growth media decreased chlorophyll and carotenoid contents (Wouter et al., 2002).

\section{Catalase specific activity}

The increase in CAT activity demonstrated in Tab. 2 is therefore, circumstantial evidence to support hypothesis that $\mathrm{Cd}$ treatment causes the formation of ROS. The specific activity of catalase enzyme was increased by increasing the $\mathrm{Cd}$ concentration, and reached its maximum value with $25 \mathrm{ppm}$ of Cd in leaves ( 58.8 unit mg protein ${ }^{-1}$ ) and in roots ( 49.8 unit mg protein ${ }^{-1}$ ). In contrast at highest con- centration of Cd (50 ppm), the activity of CAT has been decreased relative to previous concentration of $\mathrm{Cd}(25$ $\mathrm{ppm}$ ) in both tissues (leaves and roots). The present data proved that $\mathrm{Cd}$, like other heavy metals, induces specific responses from the plant antioxidant defense system including the increased activity of CAT (Arleta et al., 2001). The reduction of CAT specific activity in highest concentration of $\mathrm{Cd}$ may be due to the long-term stress exposure (Chaoui et al., 1997). The reasons for the increase in catalase activity after $\mathrm{Cd}$ treatments may be due to the scavenging role of CAT to $\mathrm{H}_{2} \mathrm{O}_{2}$, which could be quenched by the induction of specific enzymes like catalase (Elstner $e t$ al., 1988). Generally, catalase activity increased as heavy metals concentration increased and decreased at higher concentration for long-term exposure. The present results are in agreement with those reported by Arleta et al. (2001); Vitória et al. (2001); Dixit et al. (2001); El-Beltagi et al. (2008); Salama et al. (2009); Shehab et al. (2010).

\section{Glutathione S-transferase specific activity}

$\mathrm{Cd}$ treatment caused a significant increase in GST specific activity in both roots and leaves (Tab.2). GST activity at highest concentration of Cd (50 ppm) reached $459 \%$ in leaves and $756 \%$ in roots of control plants. Excess concentrations of $\mathrm{Cd}$ are known to cause cellular oxidative damage and lipid peroxidation. GST binds to $\mathrm{Pb}, \mathrm{Zn}, \mathrm{Cd}$ and Cu metal ions (Tommey et al., 1991). So the Cd-induced increase in GST activity in the present study as a result to a detoxification response (Edwards, 1996). The induction of GST provides additional defense against metal toxicity and keeps the metabolic activities in roots and leaves functional. GST is known to be responsive to both biotic and abiotic stresses. This enzyme has not been characterized with respect to its antioxidative roles in plants (Dixit et al., 2001).

\section{Peroxidase specific activity}

Peroxidase activity was increased with the increase of $\mathrm{Cd}$ treatments. The results showed that peroxidase specific activity increased by increasing $\mathrm{Cd}$ concentration and reached its maximum at highest concentration. The value of enzyme activity was 32.61 and 145 units mg protein ${ }^{-1}$ 
80

Leaf

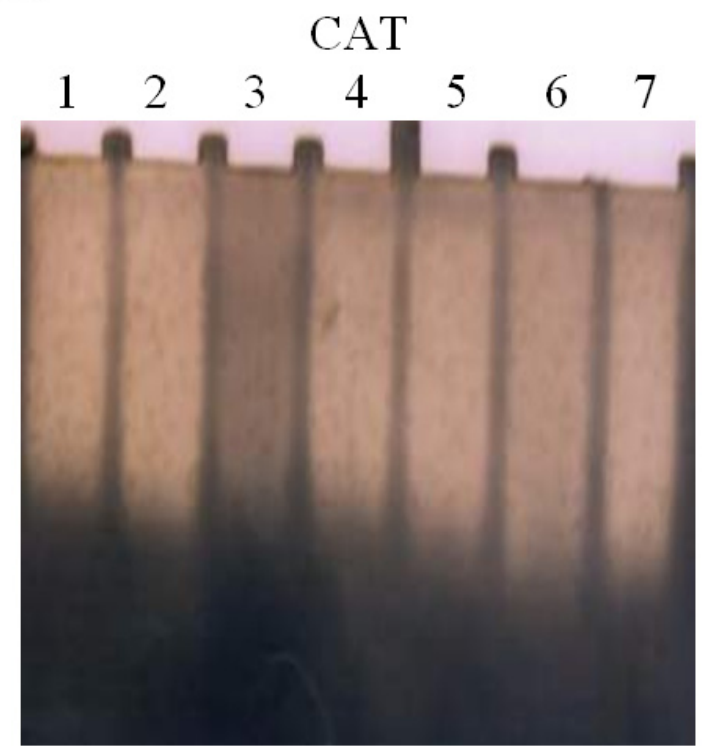

Leaf

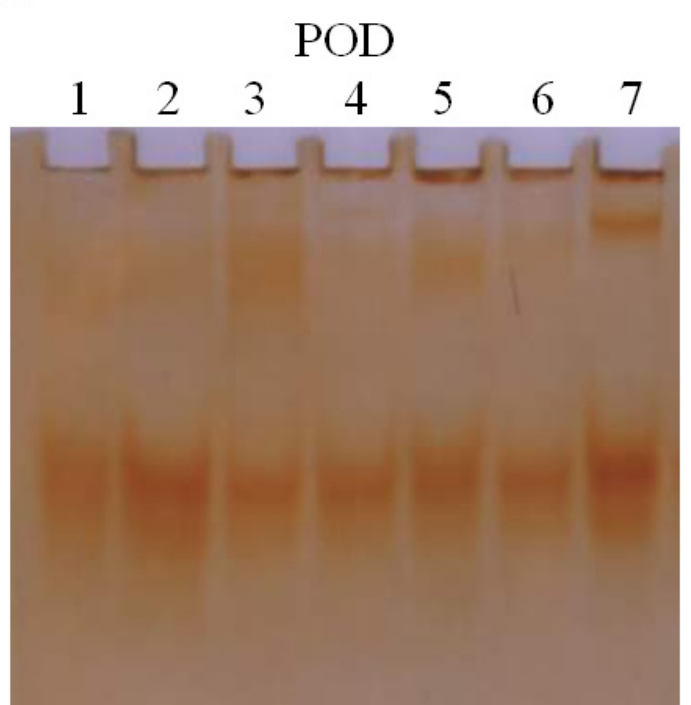

Root

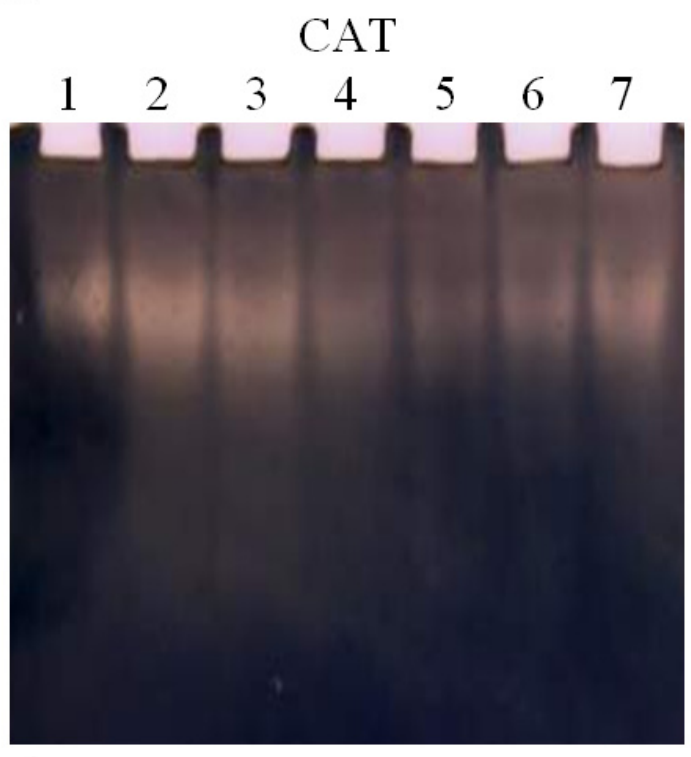

Root

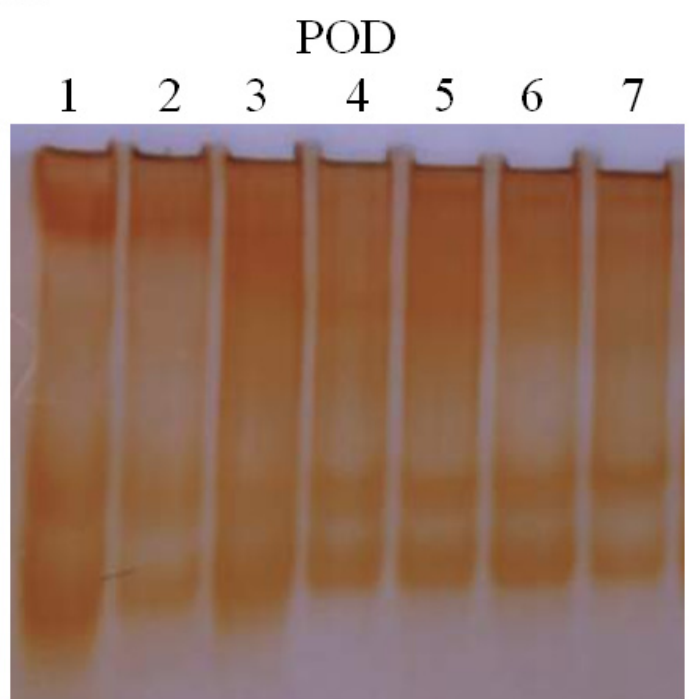

Fig. 3. Catalase and peroxidase isoenzyme patterns of radish tissues (leaves and roots) at harvest time (40 days growth) in plants grown in $\mathrm{Cd}$ containing media.

Lanes:1: Cd 0.0 ppm (control); 2: Cd 1.0 ppm; 3: Cd 2.5 ppm; 4: Cd 5.0 ppm; 5: Cd 10 ppm; 6: Cd 25 ppm; 7: Cd 50 ppm.

for $50 \mathrm{ppm} \mathrm{Cd}$ for leaves and roots, respectively compared to control 4.9 and 10.42 units $\mathrm{mg}$ protein ${ }^{-1}$ for leaves and roots, respectively as shown in Tab. 2. Van Assche and Clijsters (1990) cited that peroxidase induction is a general response in roots and leaves of higher plants to uptake of toxic doses of $\mathrm{Zn}, \mathrm{Cd}, \mathrm{Cu}, \mathrm{Ni}$ and $\mathrm{Pb}$. Van Assche and Clijsters (1988) noted that POD induction is significantly correlated to the level of $\mathrm{Zn}, \mathrm{Cd}, \mathrm{Pb}$ and $\mathrm{Cu}$ in the tissues, and with the degree of growth inhibition, observed on these plants. During heavy metal stress, intermediary forms of oxygen, $\left(\mathrm{H}_{2} \mathrm{O}_{2}\right.$, hydroxyl and superoxide radicals) are formed. These very reactive molecules could be quenched by the induction of specific enzymes like POD, SOD and CAT (Elstner et al., 1988). Dixit et al. (2001) stated that $\mathrm{Cd}$ enhances the level of lipid peroxidation and increasing tissue concentration of $\mathrm{H}_{2} \mathrm{O}_{2}$ in both roots and leaves of pea plants and causes oxidative damage to plants. He found that increasing of POD activity in both roots and leaves show that it was functioning concurrently to remove $\mathrm{H}_{2} \mathrm{O}_{2}$.

\section{Catalase and peroxidase isozymes}

The induction of new isozymes and the change in the isozyme profile is considered to play an important role in the cellular defense against oxidative stress, caused by toxic metal exposure. Among this enzymatic system, CAT and POD isozymes in both leaves and roots subjected to $\mathrm{Cd}$ stress are presented to Fig. 3. When protein extracts were 
separated by native electrophoresis, one CAT isoenzyme in varying density was observed in both leaves and roots. This result agreed with the results of (Vitória et al., 2001; El-Beltagi et al., 2008). This band is very similar in its mobility in control and Cd treated leaf tissues except its density was increased under $\mathrm{Cd}$ stress, and reached its maximum at highest concentration of $\mathrm{Cd}(50 \mathrm{ppm})$. This result agreed with that of Vitória et al. (2001). However, in root tissue, the density was lower after treatment by Cd concentration especially at 5 and $10 \mathrm{ppm}$ and then increased at 25 and $50 \mathrm{ppm}$ treatments compared to control. Results of POD isozyme showed that, a new slow band appeared in leaves $\mathrm{Cd}$ treated plants and reached its maximum density at concentration of $\mathrm{Cd} 50 \mathrm{ppm}$, where the control and low $\mathrm{Cd}$ concentration 1 and 2.5 ppm not expected any band. Also the major bands were increased in its density with $\mathrm{Cd}$ treatments and reached its maximum density at concentration of Cd $50 \mathrm{ppm}$ this result agreed with that of Van Assche and Clijsters (1986). However in root sample, one slow band was disappeared under treatments 5, 10,25 and 50 ppm Cd compared to control. Also one fast band was disappeared with $\mathrm{Cd}$ at concentration $50 \mathrm{ppm}$, and other slow and fast bands were much less dense at in the same treatment of Cd compared to control.

\section{Conclusions}

It can be concluded that $\mathrm{Cd}$ causes oxidative stress as evidenced by the decreases in the leaf area, chlorophyll and carotenoid and micronutrient contents. Moreover, the data demonstrated a significant increment in the activities of three major enzymes, which are involved in the detoxification of ROS (CAT, GST and POD). However, the magnitude of this activity's increase varies with both the enzyme and location, in leaves or roots. It remains to be seen whether these increases due to induced gene transcriptional and de novo synthesis of protein, or are due to posttranslational modification of existing protein.

\section{Acknowledgments}

Authors would like to thank to the management of the Faculty of Agriculture, Cairo University for ongoing cooperation to support research and that provided funds and facilities necessary to achieve the desired goals of research.

\section{References}

Aebi, H. (1983). Catalase, pp. 273-277. In: Bergmeyer H. (Eds.). Methods of Enzymatic Analysis, vol 3. Verlag Chemie, Weinheim, Adamse.

Arleta, M., J. Wieslawa and T. Barbara (2001). Antioxidative defense to lead stress in subcellular compartments of pea root cells. Acta Biochim Polonica 48(3):687-698.

Azevedo, R. A., R. M. Alas, R. J. Smith and P. J. Lea (1998). Response of antioxidant enzymes to transfer from elevated carbon dioxide to air and ozone fumigation, in the leaves and roots of wild-type, and a catalase-deficient mutant of barley. Physiologia Plantarum 104:280-292.

Bradford, M. M. (1976). A rapid and sensitive method for the quantitation of microgram quantities of protein utilizing the principle of protein-dye binding. Anal. Biochem. 72:248254.

Chaoui, A., S. Mazhoudi, M. Ghorbal and E. El-Ferjani (1997). Cadmium and zinc induction of lipid peroxidation and effects on antioxidant enzyme activities in bean (Phaseolus vulgaris L.). Plant Sci. 127:139-147.

Dixit, V., V. Pandey and R. Shyam (2001). Differential antioxidative responses to cadmium in roots and leaves of pea. J. Exp. Bot. 52(358):1101-1109.

Edwards, R. (1996). Characterization of glutathione S-transferases and glutathione peroxidases in pea (Pisum sativum). Physiol. Plant. 98:594-604.

El-Beltagi, H. S., Z. A. Salama, D. M. El-Hariri (2008). Some Biochemical Markers for Evaluation of Flax Cultivars under Salt stress conditions. J. Natural Fibers 5(4):316-330.

Elstner, E. F., G. A. Wagner and W. Schutz (1988). Activated oxygen in green plants in relation to stress situations. Curr. Top. Plant Biochem. Physiol. 7:159-189.

Gussarson, M., H. Asp, S. Adalsteinsson and P. Jensen (1996). Enhancement of cadmium effects on growth and nutrient composition of brich (Beyula pendula) by buthioine sulphoximine (BSO). J. Exp. Bot. 47:211-215.

Habig, W. H. and W. B. Jacoby (1981). In: S. P. Colowick and N. O. Kaplan (Eds.), Methods in Enzymology. Academic Press, New York.

Halliwell, B. and J. M. C. Gutteridge (1989). Protection against oxidants in biological systems: the superoxide theory of oxygen toxicity, pp. 86-123. In: Halliwell B. and J. M. C. Gutteridge (Eds.). Free Radicals in Biology and Medicine, Clarendon Press, Oxford.

Helene, E. L., F. B. Janet and A. Hakan (1998). Influence of UV-B radiation and $\mathrm{Cd}^{2+}$ on chlorophyll florescence, growth and nutrient content in Brassica napus. J. Exp. Bot. 49(323):1031-1039.

Hemeda, H. M. and B. P. Klein (1990). Effects of naturally occurring antioxidants on peroxidase activity of vegetable extracts. J. Food Sci. 55:184-185.

Hendry, G. A. F., A. J. M. Baker and C. F. Ewart (1992). Cadmium tolerance and toxicity, oxygen radical processes and molecular damage in cadmium-tolerant and cadmiumsensitive clones of Holcus lanatus. Acta Bot. Neerl. 41:271281.

Hogland, D. R. and D. I. Arnon (1950). The water culture method for growing plants without soil. Col. Agric. Exp. Stn. Cric. 347:1-32.

Kupper, H., F. Kupper and M. Spiller (1998). In situ detection of heavy metal substituted chlorophyll in water plants. Phytosynth. Res. 58:123-133. 
82

Laemmli, U. K. (1970). Cleavage of structural proteins during the assembly of the head of bacteriophage T4. Nature 227:680-685.

Lichtenthaler, H. K. (1987). Chlorophyll and carotenoids: pigments of photosynthetic biomembranes. Methods Enzymol. 148:350-382.

Lozano-Rodriguez, E., L. E. Hernandez, P. Bonay and R. O. Carpena-Ruiz (1997). Distribution of cadmium in shoot and root tissues of maize and pea plants: physiological disturbances. J. Exp. Bot. 48(306):123-128.

Mohamed, A. A., H. S. El-Beltagi and M. M. Rashed (2009). Cadmium stress induced change in some hydrolytic enzymes, free radical formation \& ultrastructural disorders in radish plant. EJEAFChe 8(10):969-983.

Polidoros, A. N. and J. G. Scandalios (1999). Role of hydrogen peroxide and different classes of antioxidants in the regulation of catalase and glutathione S-transferase gene expression in maize (Zea mays L.). Physiol. Plant. 106:112-120.

Ros Barcelo, A. (1987). Quantification of lupin peroxidase isoenzymes by densitometry. Ann. Biol. 14:33-38.

Salama, Z. A., H. S. El-Beltagi and D. M. El-Hariri (2009). Effect of Fe deficiency on antioxidant system in leaves of three flax cultivars. Notulae Botanicae Horti Agrobotanici Cluj-Napoca 37(1):122-128.

Sandalio, L. M., H. C. Dalurzo, M. Gomez, M. C. RomeroPuertas and L. A. Rio (2001). Cadmium-induced changes in the growth and oxidative metabolism of pea plants. J. Exp. Bot. 52(364):2115-2126.

Sanitá di Toppi, L. and R. Gabbrielli (1999). Response to cadmium in higher plants. Environ. Exp. Bot. 41:105-130.

Shehab G. G., O. K.Ahmed, H. S. El-Beltagi (2010). Effects of Various Chemical Agents for Alleviation of Drought Stress in Rice Plants (Oryza sativa L.). Notulae Botanicae Horti Agrobotanici Cluj-Napoca 38(1):139-148.

Somashekaraiah, B., K. Padmaja and A. Prasad (1992). Phytotoxicity of cadmium ions on germinating seedling of mung bean (Phaseolus vulgaris L.): Involvement of lipid peroxides in chlorophyll degradation. Physiol. Plant. 85:8589.
Stefanov, K., K. Seizova, N. Yanishlieva, E. Marinova and S. Popov (1995). Accumulation of lead, zinc and cadmium in plant seeds growing in metalliferous habitats in Bulgaria. Food Chem. 54(3):311-313.

Tommey, A., J. Shi, W. Lindsay, P. Urwin and N. Robinson (1991). Expression of the pea gene PsMTA in E. coli metal binding properties of the expressed protein. FEBS Letters 292:48-52.

Van Assche, F., C. Cardinales and H. Clijsters (1984). Premature leaf ageing induced by heavy metal toxicity. Arch. Int. Physiol. Biochem. 94:27-28.

Van Assche, F. and H. Clijsters (1986). Inhibition of photosynthesis in Phaseolus vulgaris by treatment with toxic concentration of zinc: effects on electron transport and photophosphorylation. Physiol. Plant. 66:717-721.

Van Assche, F. and H. Clijsters (1988). Biological evaluation of soil phytotoxicity in the surroundings of a zinc smelter, pp. 466-468. In: Orio A. A. (Eds.), Environmental Contamination, CEP Consultants, Edinburgh.

Van Assche, F. and H. Clijsters (1990). Effects of metals on enzyme activity in plants. Plant, Cell Environ. 13:195-206.

Vitória, A. P., P. J. Lea and R. A. Azevedo (2001). Antioxidant enzymes responses to cadmium in radish tissues. Phytochimistry 57:701-710.

Woodbury W., A. K. Spencer and M. A. Stahmann (1971). Animproved procedure using ferricyanide for detecting catalase isozymes. Anal. Biochem. 44:301-305.

Wouter, G., V. Jaco, C. Domy, C. V. Lucien and C. Herman (2002). Effects of Pb-EDTA and EDTA on oxidative stress reactions and mineral uptake in Phaseolus vulgaris. Physiol. Plant. 115:377-384. 